\title{
Erratum: Important missiological perspectives from the acts of Dordrecht for a missional church in the 21st century
}

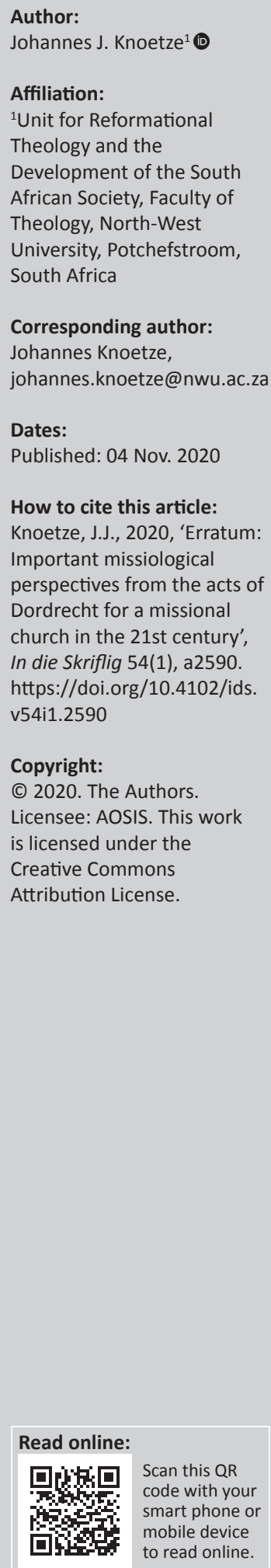

In the version of this article initially published, Knoetze, J.J., 2019, 'Important missiological perspectives from the acts of Dordrecht for a missional church in the 21st century', In die Skriflig 53(4), a2533. https://doi.org/10.4102/ids.v53i4.2533, the article issue number was given incorrectly. The correct issue number should be number 3 instead of number 4 .

This correction does not alter the study's findings of significance or overall interpretation of the study's results. The publisher apologises for any inconvenience caused. 


\section{Important missiological perspectives from the acts of Dordrecht for a missional church in the 21st century}

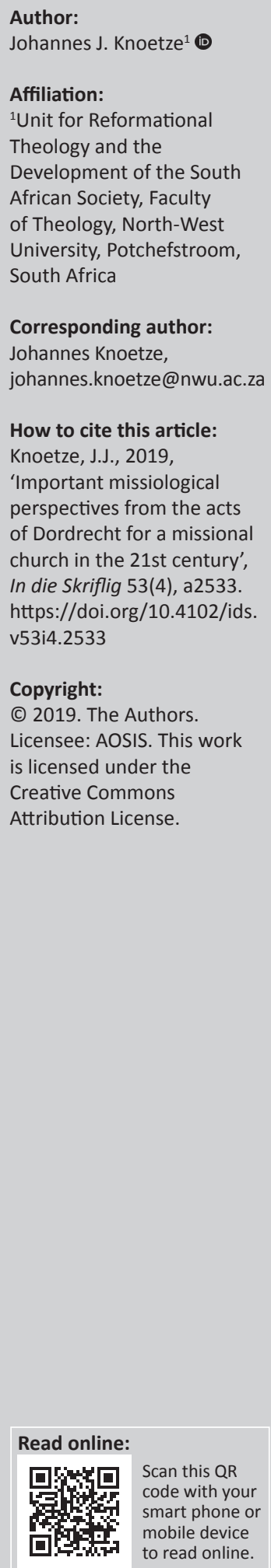

Firstly, I want to thank In die Skriflig / In Luce Verbi for the opportunity to publish a commemorative issue in 2019 of the 400-year celebration of the Synod of Dordrecht (1618-1619) with a specific focus on the missiological perspectives. The overall theme of the publication is: Important missiological perspectives from the acts of Dordrecht for a missional church in the 21st century. This publication is the compilation of nine research articles where authors reflected on the influence of the Synod of Dordt (1618-1619) on the current missiological understanding within the specific context of (South) Africa. The authors are all missiologists from different academic institutions and different denominational backgrounds. Within this publication, the missiological richness of the influence of the Synod of Dordt as well as Gijsbertius Voetius (1589-1676) is presented in the uniqueness of each article from different theological perspectives and themes. One of the articles is written in Afrikaans, with the remaining eight written in English. In the printed copy, the articles are arranged alphabetically according to the authors' surname within three focus areas.

The first focus of this publication is on the historical missiological perspectives, with a focus on the influence of Voetius. Eugene Baron from the University of the Free State wrote an article with the title, The 1619 Dordrecht Synod's decision on 'corruptio totalis': A missional challenge for the church in terms of media reporting on corruption in South Africa. In his article, he uses the reporting of four South African newspapers on corruption (as a form of sin). Their reporting displays a different way of presenting 'sin', that is mainly as an actual sin and not as a human condition which calls for salvation. This is in response to the missio Dei, reflecting theologically on contemporary media discourse on 'sin', if it wants to address the root cause of corruption in South Africa. Although there are other ways for the church to respond to widespread corruption, this article focuses mainly on a theological contribution in terms of a broader discussion on 'sin'.

A second article from a historical perspective is The Synod of Dordt (1618-1619) and a theology of religions written by Jaco Beyers from the University of Pretoria. From the context of the Synod of Dordt, he indicates how Europe was engaging with foreign cultures and exposed to other religions through a process of geographical discoveries. Within this context, the question arises as to how Christianity relates to non-Christian religions. The contribution by the theologian, Gijsbertius Voetius (1589-1676), in creating a theological position on non-Christian religions, is paramount in discerning a theology of religions (theologia religionum). This article argues that Voetius suggests an openness towards non-Christian religions, as all humans are corrupt in nature and in need of redemption.

A plea for the honour of God: Gisbertus Voetius' mission proposals at the National Synod of Dordrecht and his mission theory, by Hans Kommers, an extraordinary lecturer at the North-West University, is the third article written from a historical perspective. This article searches for the dynamic in human terms that produced today's global church, with a focus on the role and the vision of Gisbertus Voetius (1589-1676), the father of the Reformed science of missions. The focus of this article is on Voetius' missiology in which the honour of God was his highest aim.

The second focus of the publication is on the importance and influence of the Synod of Dordt for and on current Reformed and Protestant churches. Flip Buys, an emeritus of the North-West University in his article, Missio Dei perspectives in the Canons of Dort endeavours to open a window on the synod's deliberations with the Remonstrants. He highlights some missional perspectives when the background and main emphases of the canons are examined. These include on how biblical piety, missional spirituality and its implications for the missio Dei in practice may be observed in the history before, after and during the Synod of Dort and in key sections in the Canons of Dort. 
In the article, Gisbertius Voetius (1589-1676): Some perspectives on his influence on developments in the South African Dutch Reformed Church's missiology and mission practice by Gideon van der Watt of the University of the Free State, it is argued that Voetius was the first Protestant to have developed a comprehensive 'theology of mission'. This article reflects on his missiology, and specifically its influence on developments regarding the mission practice and theology in the Dutch Reformed Church in South Africa. A current South African missional discourse with Voetius is also entertained.

The last article in this focus is by Pieter Verster, also from the University of the Free State. The title of his article is: The perseverance of the saints, persecution and mission, and its implications for Reformed churches. In the article it is indicated that the confession of saints' perseverance in the Canons of Dort gives much comfort to the Christian. The message that God, in his salvation, will always complete his act of redemption, and that he will not reject the believer once he or she has become a true Christian, are discussed. This message comforts many in times of persecution. It is argued that, for Reformed churches in their endeavour of mission, a message of great comfort can be proclaimed to all. However, theologically it is also important to challenge philosophical views where certainty of faith is rejected for a worldview of uncertainty. His conclusion is that mission becomes a wonderful act of peace for the troubled soul in a troubled world.

The last focus of this publication is the perspectives on Dordt from the Pentecostal and African traditions. I have put the Afrikaans article by Dolf Britz under this focus because of the controversy of baptism of children within the context of Pentecostalism and African traditions. The title of his article is: ' $n$ Vraag 'door de Christelijke predikanten uit Oost-Indie overgezonden': Die Dordtse Sinode (1618-1619), die sending en die doop van kinders uit nie-Christelike ouers [A question sent over by the Christian ministers from East-India: The Synod of Dordt (1618-1619), mission and the baptism of children born of nonChristian parents]. The Synod of Dordt (1618-1619) decided that children, born of non-Christian (ethnici) parents, but adopted into Christian households in East-India, should not be baptised, unless foundational teaching in the Christian doctrine and confession of faith took place. The article traces the dispute with consideration of the differentiating views that arose among the delegates as it was recorded in the original acts of the Synod. The decision had after-effects and repercussions. Britz indicates that the effects of the decision were not necessarily carried by the theology of mission, formulated in such an inspiring way by the Canons of Dordt.

Attending to the challenge of decolonisation and Africanisation of education in South Africa - also of the theological curriculum, Pieter Labuschagne from SATS, draws attention to the political influence and background of the Synod of Dordt in his article, Lessons from the Synod of Dordrecht (1618-1619): A missional hermeneutic for the decolonisation and Africanisation of the curriculum. He argues that, although the Synod of Dordrecht had its unique context and raison-d'être, it was not different to the way in which many church conflicts have been handled throughout history. Instead of arguing the matter from opposite extremes, we need to create an epistemic community of role-players, ensuring meaningful encounters. This could serve as the basis of a missional hermeneutic for change; a missional hermeneutic of mutual acceptance and collaboration.

In the last article of the publication, Henry Mbaya from the University of Stellenbosch, writes about Dordt and Pentecostal traditions: African 'Spiritual' Churches in South Africa today. He explores the possible link between the teachings of the Canons of Dordt in the Netherlands (1618-1619) and those of the Pentecostal and African Spiritual Churches in South Africa today. Some common features as well as points of divergence between the two traditions, particularly with regard to the role of Scripture, divine sovereignty and human responsibility in salvation are identified. He also highlights views on the role of the Holy Spirit in election and salvation in relation to divine grace.

In conclusion I want to thank every author who contributed to this publication and, as such, gave recognition to one of the great fathers of missiology, namely Voetius as well as the important influences of church meetings such as the Synod of Dordtrecht (1618-1619) in the kingdom of God. I pray that these articles will inspire others to surrender with more passion to study mission history and to participate in the missio Dei. 'The harvest is plentiful, but the workers are few.'

Soli Deo Gloria 